\title{
KADAR KOLESTEROL, KREATININ, UREA DARAH \\ DAN KOLESTEROL TELUR AYAM SENTUL DENGAN \\ PENAMBAHAN EKSTRAK BUAH MENGKUDU YANG DISUPLEMENTASI Cu DAN Zn
}

\section{Contents of Cholesterol, Creatinine, Urea Blood And Yolk Cholesterol in Sentul Chicken With Addition of Noni Fruit Extract Supplemented $\mathrm{Cu}$ and $\mathrm{Zn}$}

\section{Nai Nurazizah $^{1}$, Abidah Ishma Nabila ${ }^{1}$, Lovita Adriani $^{2}$, Tuti Widjastuti ${ }^{2}$, Diding Latipudin ${ }^{2}$}

\begin{abstract}
${ }^{1}$ Program Sarjana Ilmu Peternakan, Fakultas Peternakan, Universitas Padjadjaran Kampus Jatinagor, J1. Raya Bandung-Sumedang KM.21, Jatinangor-Sumedang, Jawa Barat 45363

${ }^{2}$ Fakultas Peternakan, Universitas Padjadjaran, Bandung Kampus Jatinangor, J1. Raya Bandung-Sumedang KM.21，Jatinangor-Sumedang,
\end{abstract} Jawa Barat 45363

\section{KORESPONDENSI DAN RIWAYAT ARTIKEL}

\section{Nai Nurazizah}

Program Sarjana IImu

Peternakan, Depertemen

Nutrisi Ternak dan Teknologi

Pakan, Fakultas Peternakan,

Universitas Padjadjaran,

Bandung. Kampus Jatinangor,

Jl. Raya Bandung-Sumedang

KM.21, Jatinangor-Sumedang,

Jawa Barat 45363

email :

nainurazizah9@gmail.com

Dikirim I : Januari 2020

Diterima : Februari 2020

\section{ABSTRAK}

Penelitian bertujuan untuk mengetahui pengaruh pemberian ekstrak buah mengkudu yang disuplementasi $\mathrm{Cu}$ dan $\mathrm{Zn}$ terhadap kadar kolesterol darah dan kuning telur, kreatinin, serta urea darah ayam sentul fase produksi. Penelitian dilaksanakan pada bulan Agustus hingga Oktober 2019. Pengujian sampel darah dilakukan di Laboratorium Fisiologi Ternak dan Biokimia, Fakultas Peternakan Universitas Padjadjaran Sumedang. Metode yang digunakan adalah eksperimental dengan Rancangan Acak Lengkap (RAL) dan pengaruh perlakuan menggunakan analisis Sidik Ragam dengan uji lanjut Orthogonal Polynomial. Perlakuan terdiri dari lima macam dengan empat ulangan, yaitu P0 (Ransum basal tanpa penambahan ekstrak mengkudu dan tanpa $\mathrm{Cu}$ serta $\mathrm{Zn}$ ), P1 (Ransum basal+0,3\% ekstrak buah mengkudu+15 $\mathrm{mg} \mathrm{Cu}+90 \mathrm{mg}$ $\mathrm{Zn}$ ), P2 (Ransum basal+0,6\% ekstrak mengkudu+30 mg $\mathrm{Cu}+180 \mathrm{mg} \mathrm{Zn}$ ), P3 (Ransum basal+0,9\% ekstrak buah mengkudu+45 mg Cu+270 mg Zn), dan P4 (Ransum basal+1,2\% ekstrak buah mengkudu+60 mg Cu+360 mg $\mathrm{Zn})$. Hasil penelitian menunjukkan bahwa penggunaan ransum basal+1,2\% ekstrak buah mengkudu+60 mg $\mathrm{Cu}+360 \mathrm{mg} \mathrm{Zn}$ berpengaruh nyata $(\mathrm{P}<0,05)$ terhadap 
penurunan kadar kolesterol darah namun tidak berpengaruh nyata $(\mathrm{P}>0,05)$ terhadap kadar kolesterol kuning telur, kreatinin, dan urea darah ayam sentul fase produksi.

Kata Kunci: mengkudu, biokimia, ayam sentul, $\mathrm{Cu}, \mathrm{Zn}$.

\section{ABSTRACT}

This research aimed to investigate the effects of noni fruit extract supplemented by mineral $\mathrm{Cu}$ and $\mathrm{Zn}$ given in sentul chicken diet on blood cholesterol, egg yolk cholesterol, creatinine, and blood urea nitrogen. Twenty sentul chickens with 26-35 weeks old were used in this research. The research was done from August until October 2019. Samples test was held at Physiology and Biochemistry Laboratory, Animal Husbandry Faculty, University of Padjadjaran Sumedang. The research conducted by experimental method with Completely Randomized Design (CRD) consist of five treatments and four repetitions. The treatments consist of TO (Basal diet without noni fruit extract also without $\mathrm{Cu}$ and Zn), Tl (Basal diet $+0,3 \%$ noni fruit extract $+15 \mathrm{mg} \mathrm{Cu}+90 \mathrm{mg} \mathrm{Zn}$ ), 72 (Basal diet $+0,6 \%$ noni fruit extract +30 $m g \mathrm{Cu}+180 \mathrm{mg} \mathrm{Zn}$ ), $\mathrm{T3}$ (Basal diet+0,9\% noni fruit extract $+45 \mathrm{mg} \mathrm{Cu}+270 \mathrm{mg} \mathrm{Zn}$ ), and T4 (Basal diet $+1,2 \%$ noni fruit extract $+60 \mathrm{mg} C u+360 \mathrm{mg} \mathrm{Zn}$ ). Data were analyzed by Analysis of Varience (ANOVA) followed by Orthogonal Polynomial. The result show that giving of noni fruit extract supplemented by mineral $\mathrm{Cu}$ and $\mathrm{Zn}$ significantly $(P<0,05)$ affect decreasing blood cholesterol content but did not significant $(P>0,05)$ on egg yolk cholesterol, creatinin, and blood urea nitrogen contents of Sentul chicken.

Keywords: noni fruit, biochemistry, sentul chicken, $\mathrm{Cu}, \mathrm{Zn}$

\section{PENDAHULUAN}

Sumber protein hewani yang memiliki nilai gizi tinggi adalah daging dan telur. Kebutuhan daging dan telur di Indonesia semakin meningkat seiring dengan laju pertambahan penduduk. Ayam sentul mempunyai potensi yaitu dapat menghasilkan daging dan telur yang dapat memenuhi bahan pangan asal hewani. Kadar kolesterol ayam sentul relatif tinggi dibandingkan ayam ras lokal lainnya. Kesadaran masyarakat akan pentingnya kesehatan semakin meningkat sehingga masyarakat menginginkan bahan pangan asal hewani yang rendah kolesterol.Tingginya kadar kolesterol dalam bahan pangan dapat memberikan dampak negatif bagi kesehatan salah satunya adalah pembesaran hati.

Kolesterol merupakan bagian dari lipid yang menjadi komposnen penting membran beberapa sel dalam tubuh dan beberapa lipoprotein plasma serta sebagai prekursor untuk sintesis hormon steroid dan garam empedu. Tingginya kadar kolesterol dalam darah dapat menjadi indikator tinginya kadar kolesterol dalam beberapa jaringan. Tingginya kolesterol dalam kuning telur dapat memberikan dampak negatif bagi kesehatan manusia yang mengonsumsinya. Upaya menurunkan kadar kolesterol darah dan kolesterol kuning telur salah satunya dengan menambahkan tanaman herbal ekstrak buah mengkudu yang dicampurkan ke dalam ransum.

Mengkudu (Morinda Citrifolia, L) mengandung bahan aktif yaitu alkaloid dan flavonoid yang dapat menurunkan kadar kolesterol darah dan kadar kolesterol kuning telur. Salah satu senyawa utama dalam ekstrak buah mengkudu adalah xeronine (Adriani et al., 2015) dan prekusor pembentuknya yaitu proxeronine (Ramadhina dkk., 2019), yang berperan banyak dalam metabolisme protein diantaranya mengaktifkan protein yang inaktif, memperbaiki struktur dan fungsi protein sel yang abnormal (Mushawwir dkk., 2019), mengaktifkan enzim-enzim pembentuk protein, serta mempercepat 
proses penyerapan protein di saluran pencernaan. Ekstrak buah mengkudu nyata berpengaruh terhadap parameter yang diukur dibandingkan dengan tepung mengkudu. Proses ekstraksi pada buah mengkudu dapat menurunkan kandungan zat penghambat salah satunya adalah tanin yang dapat menghambat penyerapan zat makanan pada pencernaan (Mushawwir et al., 2018).

Mineral $\mathrm{Cu}$ di dalam hati berikatan dengan enzim seruloplasmin. Seruloplasmin merupakan alat transportasi dimana mineral $\mathrm{Cu}$ disalurkan dalam aliran darah dan membantu untuk penyerapan dan transportasi besi. Mineral $\mathrm{Zn}$ banyak terdapat di seluruh tubuh, dan berperan dalam mengaktifkan berbagai enzim dalam metabolisme termasuk untuk sintesis asam amino dan protein. Mineral $\mathrm{Cu}$ dan $\mathrm{Zn}$ diharapkan dapat menghambat penyerapan lemak sehingga kolesterol dapat menurun. Penambahan mineral $\mathrm{Cu}$ dan $\mathrm{Zn}$ juga dapat membantu kerja senyawa xeronine dalam pencernaan.

Aktivitas metabolisme terjadi terus menurus dan sangat dipengaruhi oleh faktor lingkungan eksternal (Mushawwir dan Latipudin, 2011,2012). Pemberian senyawa aktif dalam ransum ternak tentunya memiliki batasan tertentu karena jika berlebihan dapat mengganggu metabolisme dan fungsi kerja organ dalam tubuh. Metabolisme protein adalah hal yang penting untuk diperhatikan khususnya pada unggas mengingat asupan protein unggas hanya berasal dari pakan, lain halnya dengan ruminansia yang mampu memanfaatkan protein mikrobial. Kreatinin dan nitrogen urea darah menjadi salah satu indikator kesehatan ginjal dimana keduanya merupakan hasil metabolit dari metabolisme protein di otot dan hati yang akan terdeposisi ke dalam aliran darah untuk kemudian difiltrasi dan dieksresikan melalui urin.

Berdasarkan hal tersebut penelitian ini penting dilakukan untuk mengetahui bagaimana pengaruh pemberian ekstrak buah mengkudu yang disuplementasi $\mathrm{Cu}$ dan $\mathrm{Zn}$ terhadap kadar kolesterol darah dan kuning telur, kreatinin, dan urea darah ayam sentul.

\section{METODE PENELITIAN}

Ternak yang digunakans dalam penelitian ini adalah ayam sentul betina sebanyak 40 ekor, dipelihara mulai umur 22 sampai dengan umur 35 minggu (fase produksi). Ayam dibagi secara acak ke dalam 40 unit kandang kemudian ditempatkan ke dalam 5 perlakuan dan dilakukan pengulangan sebanyak 4 kali, masing-masing ulangan terdiri dari 2 ekor ayam. Bobot badan ayam ditimbang di awal pemeliharaan kemudian satu minggu sekali untuk mengetahui perkembangan bobot badan ayam dan perbandingan setiap masingmasing perlakuan selama pemeliharaan.

Berikut adalah dosis perlakuan per kilogram ransum yang digunakan:

$\mathrm{P} 0$ = Ransum basal tanpa penambahan ekstrak buah mengkudu dan $\mathrm{Cu}$ serta $\mathrm{Zn}$; P1 $=$ Ransum basal $+0,3 \%$ ekstrak buah mengukudu $+15 \mathrm{mg} \mathrm{Cu}+90 \mathrm{mg} \mathrm{Zn} ; \mathrm{P} 2=$ Ransum basal $+0,6 \%$ ekstrak buah mengkudu +30 mg Cu + $180 \mathrm{mg} \mathrm{Zn;} \mathrm{P3} \mathrm{=}$ Ransum basal $+0,9 \%$ ekstrak buah mengkudu $+45 \mathrm{mg} \mathrm{Cu}+270 \mathrm{mg} \mathrm{Zn} ; \mathrm{P} 4=$ Ransum basal $+1,2 \%$ ekstrak buah mengkudu + $60 \mathrm{mg} \mathrm{Cu}+360 \mathrm{mg} \mathrm{Zn}$.

\section{Pembuatan Ekstrak Buah Mengkudu}

Ekstrak buah mengkudu diperoleh dengan tahapan pengeringan irisan buah mengkudu dengan penjemuran di bawah sinar matahari, kemudian dihancurkan hingga berbentuk tepung. Tepung buah mengkudu selanjutnya direndam dengan etanol $96 \%$ selama 24 jam, lalu disaring dengan kertas Whatmann No. 40 dan dievaporasi dengan Rotary Evaporator Buchi R-300 untuk memisahkan ekstrak kental dengan pelarutnya, kemudian dilakukan pengovenan hingga kering dan dihancurkan kembali hingga didapat ekstrak berbentuk tepung. Selanjutnya ekstrak disuplementasi dengan $\mathrm{Cu}$ dan $\mathrm{Zn}$ dengan berbagai tingkat dosis yang digunakan dalam penelitian.

\section{Analisis Statistika}


Data yang diperoleh $\begin{array}{r}\text { dianalisa } \\ \text { menggunakan }\end{array}$ Metode
Polynomial Orthogonal. Hasil akhirnya digunakan untuk mengetahui hubungan antara peubah perlakuan (Y) dan peubah perlakuan (X) seperti sebagai berikut :

$\mathrm{Y}=\alpha+\beta_{1} \mathrm{X}+\beta_{2} \mathrm{X}^{2}+\ldots+\beta_{\mathrm{n}} \mathrm{X}^{\mathrm{n}}$

\section{HASIL DAN PEMBAHASAN}

Pengaruh perlakuan terhadap kadar kolesterol plasma darah dan kuning telur ayam sentul ditampilkan dalam Tabel 1 . Kadar kolesterol darah per perlakuan berada pada kisaran normal, kecuali yang tanpa pemberian ekstrak buah mengkudu berada di atas kisaran normal. Pada pemberian 1,2\% ekstrak buah mengkudu yang disuplementasi $60 \mathrm{mg} \mathrm{Cu}$ dan $360 \mathrm{mg} \mathrm{Zn}$ terdapat penurunan kadar kolesterol darah paling rendah yaitu sebesar 111,83 mg/dL.

Guna mengetahui pola hubungan antara pengaruh penggunaan ekstrak buah mengkudu yang disuplementasi $\mathrm{Cu}$ dan $\mathrm{Zn}$ terhadap kadar kolesterol darah, dilakukan uji Polinomial Ortogonal. Hasil uji Polinomial Ortogonal menunjukkan bahwa persamaan pada bentuk linear menghasilkan perbedaan yang nyata, sehingga disimpulkan bahwa pola hubungan antara pengaruh pemberian ekstrak buah mengkudu yang disuplementasi $\mathrm{Cu}$ dan $\mathrm{Zn}$ terhadap kadar kolesterol darah adalah bersifat linear.

Grafik kadar kolesterol darah dengan pemberian ekstrak buah mengkudu yang disuplementasi $\mathrm{Cu}$ dan $\mathrm{Zn}$ hasil penelitian pada Gambar 1. Berdasarkan Gambar 1, didapatkan persamaan hasil regresi linear pada $\mathrm{Y}=-11,454+151,22 \mathrm{x}$, dan koefisien determinasi adalah $0,9086\left(\mathrm{R}^{2}=90,86\right)$. Hasil anaisis koefisien determinasi $\left(\mathrm{R}^{2}\right)$ menunjukkan bahwa persentase sumbangan variabel bebas (level ekstrak buah mengkudu yang disuplementasi $\mathrm{Cu}$ dan $\mathrm{Zn}$ ) terhadap variabel terikat (kadar kolesterol darah) adalah sebesar $90,86 \%$.

Gambar 1 menunjukkan bahwa penggunaan ekstrak buah mengkudu yang disuplementasi $\mathrm{Cu}$ dan $\mathrm{Zn}$ pemberiannya meningkat maka kadar kolesterol darah mengalami penurunan. Hal ini sesuai dengan literatur bahwa zat aktif yang terdapat dalam buah mengkudu yaitu alkaloid mampu menurunkan kadar kolesterol darah yaitu dengan membantu kerja HMG - KoA dalam proses sintesis kolesterol yang mampu meningkatkan sekresi empedu dan zat NO (Nitrit Oxide) dan dapat memacu eksresi kolesterol melalui tinja, jika kolesterol banyak yang terbuang melalui tinja, kolesterol dalam darah dan jaringan akan menurun (Maslachah, 2005).

Hasil ini menunjukkan bahwa ekstrak buah mengkudu yang mengandung zat aktif alkaloid mampu meningkatkan sintesis garam empedu yang dapat menurunkan kadar kolesterol darah, dalam penelitian ini sudah memberikan pengaruh yang nyata. Hal ini didukung oleh pernyataan Adriani et al., (2015) yang menegaskan bahwa pemberian ekstrak buah mengkudu yang mengandung zat aktif alkaloid mampu menurunkan kadar kolesterol darah. adanya kandungan flavonoid dalam ekstrak buah mengkudu yang mampu melindungi pembuluh arteri dari kerusakan, mengurangi jumlah penimbunan kolesterol dipermukaan endotel darah arteri (Fuhrman et al., 2001). Flavonoid mempunyai sifat aromatik dan merupakan senyawa-senyawa flavon yang mengandung banyak gugus hidroksil. Jenis flavonoid yaitu flavon, flavonol, antosianidin, isoflavon, phenylalanin dan antosianin (Maslach, 2005). Flavonoid mempunyai banyak gugus hidroksil atau hidroksiflavon dan mempunyai struktur hidroksil komplit. Setelah diuji aktivitas antiokidan yaitu uji DPPH, kandungan antioksidan yang terdapat dalam flavonoid nilainya rendah itu artinya aktivitas antioksidanya lebih tinggi sehingga upaya penurunan kandungan kolesterol lebih tinggi. Flavonoid merupakan suatu hidroksiflavon yang dapat menurunkan kadar kolesterol darah pada ayam sentul. Batasan penggunaan flavonoid yaitu 0,5\%. Flavonoid jika jumlahnya cukup maka akan menjadi protektif (pelindung), namun jika flavonoid lebih dari rata-rata makan akan menjadi hepatoksit (racun pada hati). 
Kadar kolesterol kuning telur selalu tinggi dibandingkan kandungan kolesterol et al., (2001) menyatakan bahwa proses penurunan kolesterol salah satunya senyawa

Tabel 1. Kadar Kolesterol Plasma Darah dan Kuning Telur Ayam Sentul

\begin{tabular}{lcccrr}
\hline \multirow{2}{*}{ Kolesterol } & \multicolumn{5}{c}{ Perlakuan } \\
\cline { 2 - 6 } & $\mathrm{P}_{0}$ & $\mathrm{P}_{1}$ & $\mathrm{P}_{2}$ & $\mathrm{P}_{3}$ & $\mathrm{P}_{4}$ \\
\hline Plasma. mg/dL & $155,86^{\mathrm{a}}$ & $139,79^{\mathrm{a}}$ & $120,78^{\mathrm{a}}$ & $113,24^{\mathrm{b}}$ & $111,83^{\mathrm{b}}$ \\
Kuning Telur mg/100g & $198,40^{\mathrm{a}}$ & $187,23^{\mathrm{a}}$ & $190,33^{\mathrm{a}}$ & $180,85^{\mathrm{a}}$ & $182,27^{\mathrm{a}}$
\end{tabular}

Keterangan: Notasi huruf yang berbeda pada baris yang sama menunjukan perbedaan yang nyata $(\mathrm{P}<0,05)$

darah dikarenakan telur merupakan akhir dari distribusi vitelogenin yang tersusun oleh kolesterol, trigliserida, fosfolipid dan protein. Vitelogenin disintesis di hati yang dikemas dalam bentuk VLDL (Very Low Density Lipoprotein). Kemudian ditransferkan kedalam ovarium dan diakumulasikan dalam folikel sebagai kuning telur (Salvante et al., 2007; Mushawwir et al., 2017). Kadar kolesterol kuning telur akan meningkat sejalan dengan meningkatnya kadar kolesterol darah. Deposisi kolesterol dalam telur banyak dipengaruhi berbagai faktor antara lain faktor genetik, nutrient dan obatobatan. Kolesterol dalam kuning telur dapat berubah-ubah yang mencapai $25 \%$ oleh aktif alkaloid dapat mampu meningkatkan sintesis garam empedu yang mengakibatkan menurunnya kadar kolesterol, namun pada penelitian ini belum memberikan pengaruh nyata. Kadar kolesterol kuning telur yang tidak menurun dikarenakan kolesterol kuning telur merupakan distribusi akhir dari vitelogenin, komposisi vitelogenin diantaranya kolesterol, fosfolipid, protein dan trigliserida serta metabolism secara keseluruhan (Mushawwir dan Latipudin, 2012; Suwarno dan Mushawwir, 2019).

Berdasarkan hasil penelitian, pengaruh perlakuan terhadap kadar kreatinin dan urea darah ayam sentul fase produksi

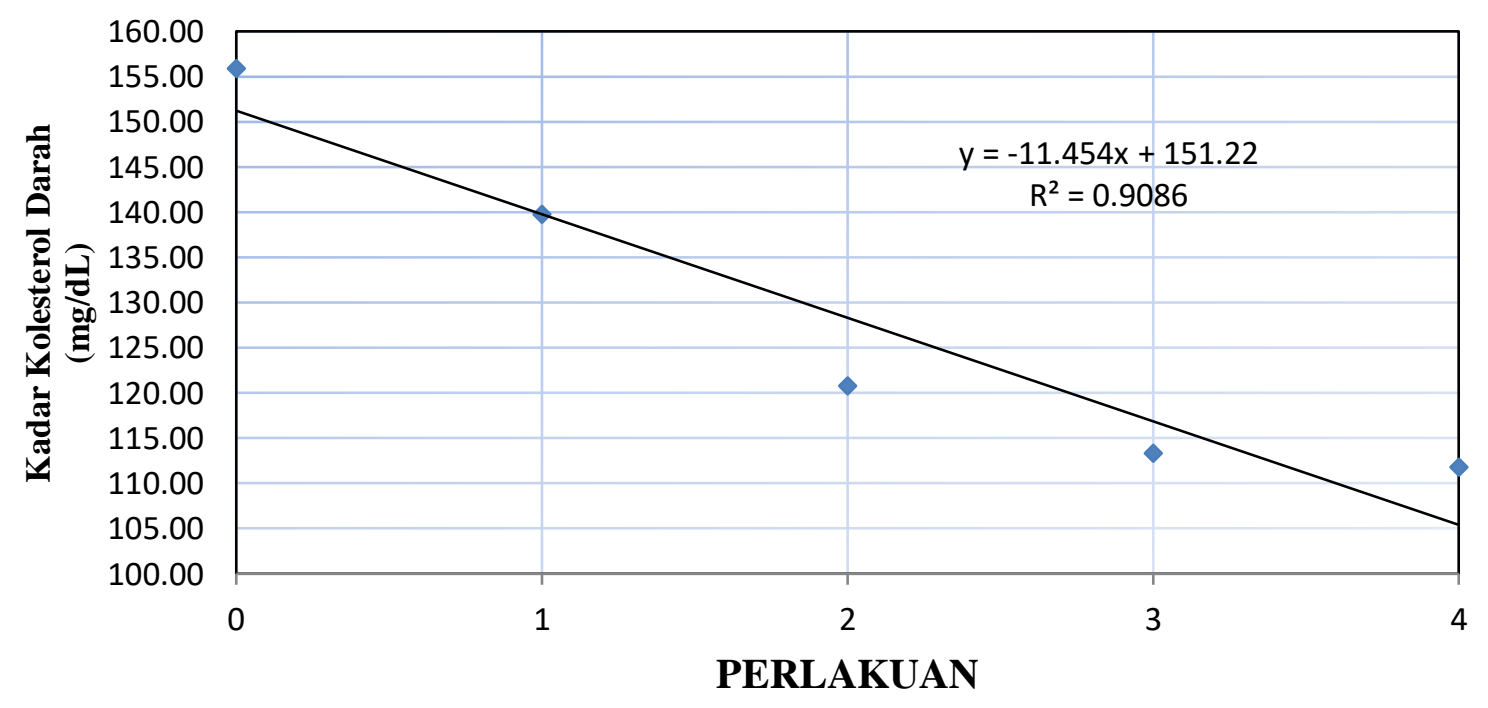

Gambar 1. Grafik kadar kolesterol darah dengan pemberian ekstrak buah mengkudu yang disuplementasi $\mathrm{Cu}$ dan $\mathrm{Zn}$ hasil penelitian

kolesterol dari pakan dan lemak yang dikonsumsi (Hargin, 1988). Menurut Koshy tersaji dalam Tabel 2. Hasil analisis sidik ragam menunjukkan bahwa pemberian 
ekstrak buah mengkudu yang disuplementasi mineral $\mathrm{Cu}$ dan $\mathrm{Zn}$ tidak berpengaruh nyata $(\mathrm{P}>0,05)$ terhadap kadar kreatinin dan urea darah ayam sentul fase produksi. Nilai rataan kadar kreatinin darah setelah dilakukan percobaan sebesar $0,10-0,22 \mathrm{mg} / \mathrm{dL}$ masih tergolong dalam rentang normal, dimana kadar kreatinin darah ayam normal pada kisaran 0,10-0,40 mg/dL (Hochleitner, 2013).

Pemberian ransum dengan penambahan $0,9 \%$ ekstrak buah mengkudu, $45 \mathrm{mg} \mathrm{Cu}$, dan $270 \mathrm{mg} \mathrm{Zn}$ (P3) memberikan hasil rataan kadar kreatinin darah tertinggi yaitu mencapai $0,22 \mathrm{mg} / \mathrm{dL}$ plasma darah. Hasil ini berbeda kontras dengan kontrol perlakuan (P0) dimana rataan kadar kreatinin mencapai nilai terendah dari seluruh perlakuan yaitu sebesar $0,10 \mathrm{mg} / \mathrm{dL}$.

Kreatinin bermula dari kreatin yang disintesis secara bertahap di ginjal dan hati ke dalam aliran darah untuk dihantarkan ke sel-sel tubuh kemudian bekerja dengan mengaktifkan protein-protein yang inaktif serta memperbaiki struktur dan fungsi protein sel yang rusak, termasuk pada jaringan hati (Dinana dkk, 2019) sebagai salah satu tempat sintesis kreatin serta ginjal yang juga berperan dalam proses filtrasi kreatinin oleh glomerulus yang tentunya proses tersebut menjadi lebih optimal, menyebabkan kreatinin yang tetap beredar di dalam darah selalu terjaga dalam kadar yang normal. Hal ini sejalan dengan penelitian sebelumnya yang dilakukan oleh Rahmawati (2009) bahwa sel tubuh yang dimasuki xeronine akan menjadi lebih aktif, sehat, dan mengalami perbaikan struktur maupun fungsi.

Kadar kreatinin darah juga berkaitan erat dengan kondisi cekaman panas yang

Tabel 2. Nilai Rataan Kadar Kreatinin dan Urea Darah Ayam Sentul Fase Produksi

\begin{tabular}{lccccc}
\hline \multirow{2}{*}{ Parameter } & \multicolumn{5}{c}{ Perlakuan } \\
\cline { 2 - 6 } & P0 & P1 & P2 & P3 & P4 \\
\hline Kreatinin $(\mathrm{mg} / \mathrm{dL})$ & $0,10^{\mathrm{a}}$ & $0,14^{\mathrm{a}}$ & $0,14^{\mathrm{a}}$ & $0,22^{\mathrm{a}}$ & $0,13^{\mathrm{a}}$ \\
Urea $(\mathrm{mg} / \mathrm{dL})$ & $7,18^{\mathrm{a}}$ & $6,08^{\mathrm{a}}$ & $5,47^{\mathrm{a}}$ & $6,86^{\mathrm{a}}$ & $7,36^{\mathrm{a}}$ \\
\hline
\end{tabular}

Keterangan: Notasi hurut yang sama pada baris yang sama menunjukan tidak berbeda nyata $(\mathrm{P}>0,05)$

yang kemudian dibawa ke otot dan disimpan sebagai fosfokreatin. Fosfokreatin sebagai cadangan pemberi gugus fosfat berenergi tinggi pada otot akan mengalami perombakan sehingga terbentuklah kreatinin. Kreatinin dilepas ke dalam aliran darah dan dibawa menuju organ ginjal untuk difiltrasi kemudian dieksresikan melalui urin (Lehningher, 1982).

Dalam saluran pencernaan, proxeronine dari ekstrak buah mengkudu diubah oleh enzim proxeronase menjadi xeronine (Bangun, A.P., dkk., 2002). Xeronine diserap oleh usus halus lalu masuk diterima ayam selama pemeliharaan. Kondisi demikian menyebabkan ayam mengalami panting sebagai mekanisme pertahanan suhu tubuh melalui pengeluaran panas berlebih. Otot-otot rangka, dada, dan perut bekerja maksimal memompa panas keluar dari tubuh, dimana ATP banyak digunakan untuk kontraksi menyebabkan pembentukan ADP yang banyak pula (Mushawwir et al, 2010; 2011). Lehninger (1982) menambahkan dalam kondisi demikian konsentrasi ATP tidak konstan, sehingga diperlukan buffer untuk menjaga ketersediaan energi dalam jumlah banyak secara cepat. Maka terjadilah 
perombakan fosfokreatin dengan dikatalisasi enzim kreatin kinase, sehingga gugus fosfat berenergi tinggi ditransfer kepada ADP, membentuk ATP serta hasil samping berupa kreatin yang kemudian diubah menjadi kreatinin melalui suatu reaksi dehidratasi.

Hasil penelitian memperlihatkan bahwa pemberian ekstrak buah mengkudu yang mengandung antioksidan dapat menanggulangi dampak cekaman panas. Penelitian sebelumnya dari Su, dkk (2005) menyatakan bahwa ekstrak buah mengkudu memiliki aktivitas antioksidan yang signifikan dengan adanya beberapa senyawa diantaranya americanin A dan narcissosida. Syamsu Hidayat dan Hutapea (1991) menambahkan bahwa buah mengkudu juga mengandung asam askorbat (vitamin C) yang berperan sebagai antioksidan. Senyawa antioksidan dari ekstrak buah mengkudu akan mendonorkan elektron kepada radikal bebas yang menyebabkan stress oksidatif, sedangkan asam askorbat yang bertindak sebagai kosubstrat dari dopamin $\beta$ hidroksilase dalam pembentukan norepineprin, akan mendonorkan elektron dalam reaksi penggabungan iodium pada pembentukan tiroksin sehingga kadar hormon tersebut mengalami peningkatan. Meningkatnya kadar hormon tiroksin menyebabkan kemampuan ayam dalam membuang panas tubuh dengan memacu denyut jantung dan dilatasi pembuluh darah perifer menjadi lebih optimal (Mitzler, 1977). Kondisi demikian menyebabkan otot-otot rangka tidak perlu mengalami kerja lebih dengan perombakan fosfokreatin sehingga kreatinin darah yang dirilis mengalami penurunan (Mushawwir dkk., 2019; Sahara dkk., 2019).

Kadar kreatinin yang berfluktuasi pada tiap perlakuan bergantung pada beberapa faktor fisiologis masing-masing individu termasuk ketahanan tubuh terhadap cekaman panas yang berujung pada panting, laju metabolisme protein dan pertambahan bobot badan yang berkorelasi positif dengan peningkatan kadar kreatinin, serta kondisi organ hati serta ginjal yang berperan dalam sintesis kreatin dan eksresi kreatinin.

Urea nitrogen darah adalah konsentrasi urea dalam plasma atau serum darah yang jumlahnya bergantung pada tingkat katabolisme asam amino di hati. Dari hati, urea yang diproduksi didistribusikan menuju ginjal untuk difiltrasi dan dieksresikan melalui urin (Murray dkk., 2009). Urea nitrogen darah lebih menjadi penanda yang akurat terhadap kesehatan organ hati (Tanuwiria, 2007, dimana penurunan kadarnya dapat menjadi salah satu indikasi adanya kerusakan sel-sel hati. Kadar urea darah ayam sentul fase layer berfluktuasi normal pada rentang 5,47-7,36 mg/dL plasma darah, sebagaimana dinyatakan oleh Howel (1987) bahwa kadar urea darah normal pada kisaran 3,3-7,70 mg/dL.

Pada Tabel 2 tampak bahwa pemberian $1,2 \%$ ekstrak mengkudu yang disuplementasi $60 \mathrm{mg}$ Cu dan $360 \mathrm{mg} \mathrm{Zn} \mathrm{(P4)}$ sebagai tingkat pemberian tertinggi menunjukkan nilai rataan kadar nitrogen urea darahnya paling tinggi dibandingkan dengan seluruh perlakuan yaitu sebesar 7,36 mg/dL, sementara sampel dengan tingkat pemberian P2 (0,6\% ekstrak mengkudu+30 mg Cu+180 mg Zn) memiliki rataan kadar nitrogen urea darah terendah yaitu $5,47 \mathrm{mg} / \mathrm{dL}$.

Tingginya kadar urea nitrogen darah pada tingkat pemberian $\mathrm{P} 4$ (1,2\% ekstrak mengkudu+60 mg $\mathrm{Cu}+360 \mathrm{mg} \mathrm{Zn)} \mathrm{dapat}$ disebabkan oleh korelasi yang positif antara tingginya asupan pakan yang mengandung banyak prekusor pembentuk protein serta tingginya tingkat katabolisme protein yang terjadi di hati, dimana pemberian ekstrak buah mengkudu yang mengandung xeronine dan proxeronine akan merangsang 
terbentuknya enzim-enzim pembentuk protein dalam saluran pencernaan serta meningkatkan penyerapan nutrien tersebut. Selain itu, Linder (1985) juga melaporkan bahwa mineral $\mathrm{Zn}$ turut membantu dalam mengaktifkan berbagai enzim dalam metabolisme termasuk untuk sintesis asam amino dan protein. Kondisi demikian akan meningkatkan jumlah protein dan asam amino yang dirombak di hati melalui siklus urea sehingga kadar urea darah yang dihasilkan menjadi lebih tinggi.

Sementara rendahnya kadar nitrogen urea darah pada tingkat pemberian P2 $(0,6 \%$ ekstrak mengkudu+30 mg $\mathrm{Cu}+180 \mathrm{mg} \mathrm{Zn}$ ) dapat dikarenakan protein yang diabsorpsi di saluran pencernaan dan dibawa menuju ke organ hati sedikit, sehingga protein yang dirombak pun sedikit pula dan urea yang dihasilkan berbanding lurus dengan keadaan tersebut. Hal ini sejalan dengan pernyataan Suci, dkk (2016) bahwa rendahnya protein yang dirombak di hati dapat disebabkan karena protein yang dicerna lebih banyak digunakan untuk jaringan tubuh ternak.

Kadar urea darah terlihat berfluktuasi pada tiap tingkat pemberian, menunjukkan bahwa peningkatan jumlah ekstrak buah mengkudu dan mineral $\mathrm{Cu} \mathrm{Zn}$ yang diberikan tidak secara mutlak akan menaikkan pula kadar nitrogen urea darah. Kondisi ini dapat disebabkan karena kadar urea darah tidak hanya dipengaruhi oleh asupan pakan, melainkan juga dipengaruhi oleh tingkat katabolisme protein yang terjadi di hati (Widhyari, S.D., dkk, 2015; Prince dan Wilson 1995), sehingga kadarnya bergantung pada tingkat metabolisme masing-masing individu.

Penambahan suplementasi mineral $\mathrm{Cu}$ dan $\mathrm{Zn}$ dalam ekstrak buah mengkudu yaitu untuk membantu xeronine dalam memperkuat ikatan penyerapan zat aktif yang terdapat dalam buah mengkudu.

\section{KESIMPULAN}

Berdasarkan hasil penelitian dapat disimpulkan bahwa tingkat penggunaan ekstrak buah mengkudu yang disuplementasi $\mathrm{Cu}$ dan $\mathrm{Zn}$ memberikan pengaruh terhadap penurunan kadar kolesterol darah dan tidak memberikan pengaruh terhadap penurunan kadar kolesterol kuning telur ayam Sentul. Pola hubungan antar perlakuan terhadap kadar kolesterol darah diperoleh dalam bentuk linear dengan persamaan $\mathrm{Y}=$ $11,454 x+151,22\left(R^{2}=90,86 \%\right)$. Pemberian ekstrak buah mengkudu dan mineral $\mathrm{Cu} \mathrm{Zn}$ dengan tingkat pemberian tertinggi $1,2 \%$ ekstrak, $60 \mathrm{mg} \mathrm{Cu}$, dan $360 \mathrm{mg} \mathrm{Zn}$ tidak berpengaruh nyata terhadap kadar kreatinin dan nitrogen urea darah, dimana keduanya masih berada dalam kisaran normal.

\section{UCAPAN TERIMA KASIH}

Ucapan terima kasih disampaikan kepada seluruh pihak yang telah membantu penelitian ini, hingga penulisan artikel ini telah dilaksanakan dengan kontribusi yang sama dengan seluruh tim yang terlibat seperti yang tercantum sebagai penulis dalam artikel ini.

\section{DAFTAR PUSTAKA}

Adriani, L. Abun and A. Mushawwir. 2015. Effect of dietary supplementation of Jengkol (Pithecellobium jiringa) skin extract on blood biochemistry and gut flora of broiler chicken. Int. J. of Poult. Sci. 14:407-410.

Adriani, L., T. Widjastuti, E. Sudjana, A. Mushawwir and A. Yulianti. 2015. Effect of combination of Noni (Morinda citrifolia) juice and palm sugar (Arenga pinnata) supplementation in drinking water on lipid profile of broiler chicken. Pak. J. Nutr., 14:531-534.

Bangun, A.P. dan B. Sarwono. 2002. Khasiat dan Manfaat Mengkudu. Agro Media Pustaka. Jakarta. 
Dinana, A., D. Latipudin, D. Darwis dan A. Mushawwir. 2019. Profil enzim transaminase ayam ras petelur yang diberi kitosan iradiasi. J. Nutrisi Ternak Tropis dan Ilmu Pakan 1:6-15.

Fuhrman, B. and M. Aviram, 2001. Flavonoids protect LDL from oxidation and attenuate atheroslerosis. Curr. Opin. lipidol. 12:41-8.

Hochleithner, Manfred. 2013. Avian Medicine, Principles and Application (Chapter 11: Biochemistries). 223245.

Koshy, A.S., L. Anila and N. R. Vijayalakshmi. 2001. Flavonoids from Garcinia cambogia lower lipid levels in hypercholesterolemic rats. Food Chemistry. 7:289-294.

Lehninger, A.L. 1982. Dasar-dasar Biokimia Jilid 1. Diterjemahkan oleh M. Thenawijaya. Erlangga. Jakarta.

Maslachah, L. 2005. Potensi Ekstrak Mengkudu (Morinda citrifolia L.) terhadap sekresi nitric oxide (NO) dan endothel pembuluh darah hiperkolesterolemia.Media Kedokteran Hewan. 22:136-141.

Mitzler, D.E. 1977. Biochemistry, The Chemical Reaction of Living Cell. Academic Press. New York, San Fransisco, London.

Murray, R.K., Granner, D.K., dan Rodwell, V.W. 2009. Biokimia Harper. EGC. Jakarta.

Mushawwir, A. dan D. Latipudin. 2011. Beberapa parameter biokimia darah ayam ras petelur fase grower dan layer dalam lingkungan "Upper zonathermoneutral. Jurnal Peternakan Indonesia. 13:191-198.

Mushawwir, A. dan D. Latipudin. 2012. Respon fisiologi thermoregulasi ayam ras petelur fase grower dan layer. Proseding seminar zootechniques for Indogeneous resources development, ISAA Fakultas Petenakan Universitas Diponegoro. Proceeding of National Seminar on Zootechniques. 1:23-27.

Mushawwir, A., U. H. Tanuwiria, K.A. Kamil, L. Adriani and R. Wiradimadja.
2017. Effects of volatile oil of garlic on feed utilization, blood biochemistry and performance of heat-stressed japanese quail. Asian J. of Poult. Sci. 11:83-89.

Mushawwir, A., U.H. Tanuwiria, Kurnia Kamil, L. Adriani, R. Wiradimadja, and N. Suwarno. 2018. Evaluation of haematological responses and blood biochemical parameters of heat-stressed broilers with dietary supplementation of Javanese Ginger powder (Curcuma xanthorrhiza) and garlic extract (Allium sativum). International J. of Poult. Sci . 17:452-458.

Mushawwir, A. Y.K. Yong, L. Adriani, E. Hernawan and K.A. Kamil. 2010. The fluctuation effect of atmospheric ammonia $\left(\mathrm{NH}_{3}\right)$ exposure and microclimate on Hereford bulls hematochemical. J. of the Indon. Tropical Anim. Agric. 35:232-238.

Mushawwir, A., L. Adriani and K.A. Kamil. 2011. Prediction models for olfactory metabolic and sows\% RNAreticulocyt (RNArt) by measurement of atmospheric ammonia exposure and microclimate level. J. of the Indon. Tropical Anim. Agric. 36:14-20.

Mushawwir, A., N. Suwarno and A.A. Yulianti. 2019. Profil malondialdehyde (MDA) dan kreatinin itik fase layer yang diberi minyak atsiri garlic dalam kondisi cekaman panas. J. Ilmu dan Industri Peternakan 5:1-11.

Mushawwir, A., N. Suwarno dan A.A. Yulianti. 2019. Thermoregulasi domba ekor gemuk yang dipelihara pada ketinggian tempat (Altitude) yang berbeda. J. Ilmu dan Industri Peternakan. 5:77-86.

Pemayun, I. 2002. Evaluation of Nephrotomy without Sutures in Dog. J. of Veterinary. 3:94-96.

Prince, S.A., dan Wilson, L.M. 1995. Patofisiologi Konsep Klinik ProsesProses Penyakit. Buku 2 Edisi 4. EGC. Jakarta p1-122. 
Rahmawati, A. 2009. Kandungan fenol pada buah mengkudu. Jurnal Fakultas Kedokteran Universitas Indonesia. Jakarta.

Ramadhina, I.A., L. Adriani dan E. Sujana. 2019. Pengaruh pemberian ekstrak daun kepel (stelechocarpus burahol) terhadap kadar kolesterol darah dan telur puyuh (Coturnix-coturnix japonica). J. Nutrisi Ternak Tropis dan Ilmu Pakan. 1:34-40.

Sahara, E., S. Sandi dan M.L. Sari. 2019. Dampak pemberian tepung bawah putih terhadap profil lipid liver dan plasma darah puyuh yang mengalami cekaman panas. J. Nutrisi Ternak Tropis dan Ilmu Pakan. 1:16-24.

Salvante K.G., G. Lin, R.L. Walzem and T. Williams. 2007. Characteristic of very low density lipiprotein particle diameter dynamics in relation to egg production in a passerine bird. The $\mathrm{J}$. of Experimental Biol. 210:13-56.

$\mathrm{Su}$, B.N., A.D. Pawlus, H.A. Jung, W.J. Keller, J.L. McLaughlin and A.D. Kinghorn. 2005. Chemical constituents of the fruits of Morinda citrifolia (Noni) and their Antioxidant activity. J. of Natural Products. 68:592-595.
Suci, D.M., Asella, L.W. Utami dan W. Hermana. 2018. Pengaruh pemberian ransum mengandung tepung daun mengkudu (Morinda citrifolia Linn) terhadap performa dan profil darah itik lokal periode grower. Fakultas Peternakan IPB. Bogor.

Suwarno, N. dan A. Mushawwir. 2019. Model Prediksi metabolit melalui jalur glikogenolisis berdasarkan fluktuasi mikroklimat lingkungan kandang sapi perah. J. Ilmu dan Industri Peternakan. 5:77-86.

Syamsuhidayat, S.S. dan Hutapea, J.R. 1991. Inventaris Tanaman Obat Indonesia Badan Litbang Kesehatan Depkes RI. Jakarta.

Tanuwiria, U. H. 2007. Efek suplementasi kompleks mineral-minyak dan mineral-organik dalam ransum terhadap kecernaan ransum, populasi mikroba rumen dan performa produksi domba jantan. Prosiding Seminar Nasional dan Kongres Asosiasi Ahli Nutrisi. AINI.

Widhyari, S.D., A. Esfandiari dan A.D. Cahyono. 2015. Profil kreatinin dan nitrogen urea darah pada anak sapi friesian holstein yang disuplementasi Zn. Acta Veterinaria Indonesia. 3:4550 . 